\title{
White matter abnormalities of the brain: similar to multiple sclerosis in adolescence
}

\author{
Anormalidades da substância branca do cérebro: semellhantes à esclerose múltipla na adolescência \\ Anomalías de la sustancia blanca del cerebro: similar a la esclerosis múltiple en la adolescência
}

Received: 04/19/2021 | Reviewed: 04/26/2021 | Accept: 04/28/2021 | Published: 05/12/2021

Dilceu Silveira Tolentino Júnior

ORCID: https://orcid.org/0000-0003-2435-7576

Federal University of Jequitinhonha and Mucuri Valleys, Brazil

E-mail: dilceujunior@bol.com.br

Sandra Neres Santos

ORCID: https://orcid.org/0000-0002-2542-2723

Federal University of Jequitinhonha and Mucuri Valleys, Brazil

E-mail: sandraneres2008@hotmail.com

Aquiles Castro Araújo

ORCID: https://orcid.org/0000-0002-2403-012X

Federal University of Jequitinhonha and Mucuri Valleys, Brazil

E-mail: aquiles.araujo@tre-mg.jus.br

Arlanjo Bispo de Sousa Marques

ORCID: https://orcid.org/0000-0002-1710-3298

Federal University of Jequitinhonha and Mucuri Valleys, Brazil

E-mail: arlanjomarques@hotmail.com

Kleise Pinheiro Farias

ORCID: https://orcid.org/0000-0001-8418-1643

Municipal Health Department of Crisólita, Brazil

E-mail: saudecris@yahoo.com.br

André Barbosa Souza

ORCID: https://orcid.org/0000-0001-7805-949X Municipal Health Department of Águas Formosas, Brazil

E-mail: aps.fronteiradosvales@ gmail.com

Roberto Carlos de Oliveira

ORCID: https://orcid.org/0000-0003-2407-8905

Vale do Rio Doce University, Brazil

E-mail: roberto.oliveira@univale.br

\begin{abstract}
Also known as Devic's disease, neuromyelitis optica (NMO) is an autoimmune inflammatory disease that affects the central nervous system, considerably similar to multiple sclerosis (MS). This study aimed to compare the similarities of the clinical feature presented with similar cases found in the medical literature, addressing the symptoms, diagnosis, and treatment. This is a descriptive, retrospective, and qualitative study, done through the technique of direct observation. An adolescent male patient came to our service complaining of weakness in the lower limbs and urinary retention and, subsequently, urinary incontinence, during hospitalization. After undergoing magnetic resonance imaging of the skull, a large lesion with a demyelinating characteristic was evident through the T2 and FLAIR sequences, hyperintense in the white matter of the right cerebral hemisphere, with the exuberant enhancement of the contrasted image. Subsequently, he presented weakness in the left dimidium of the body, with progressive worsening in some days, with the impossibility of walking. The treatment was initiated with pulse therapy of methylprednisolone and interferon beta, obtaining an excellent clinical control of the disease. Thus, diagnostic confirmation was only possible thanks to the identification of a single brain white matter lesion through imaging and serological examination, which constituted a tool of great importance for the differential diagnosis that made it possible to exclude multiple sclerosis and allowed the establishment of timely treatment for neuromyelitis optica. Keywords: Brain injury; White matter; Neuromyelitis Optica; Adolescent.
\end{abstract}

\section{Resumo}

Também conhecida como doença de Devic, a neuromielite óptica (NMO) é uma doença inflamatória autoimune que acomete o sistema nervoso central, consideravelmente semelhante à esclerose múltipla (EM). O objetivo desse trabalho foi comparar as semelhanças do quadro clínico apresentado com casos semelhantes encontrados na literatura médica, abordando a sintomatologia, diagnóstico e tratamento. Trata-se de um estudo descritivo, retrospectivo e qualitativo, feito através da técnica de observação direta. Paciente do sexo masculino, adolescente, compareceu ao nosso serviço queixando-se de fraqueza em membros inferiores e retenção urinária e, posteriormente, incontinência urinária, durante a internação hospitalar. Após se submeter à ressonância magnética de crânio evidenciou-se através das sequências T2 e FLAIR uma grande lesão com característica desmielinizante, hiperintensa na substância branca do hemisfério cerebral direito, com exuberante realce da imagem contrastada. Posteriormente, apresentou fraqueza 
no dimídio esquerdo do corpo, com piora progressiva em alguns dias, com impossibilidade de deambulação. O tratamento foi instituído com pulsoterapia de metilprednisolona e interferon beta, obtendo um excelente controle clínico da doença. Assim, a confirmação diagnóstica só foi possível graças a identificação de lesão única da substância branca cerebral através de exame de imagem e sorológico, que constituíram ferramentar de grande importância para o diagnóstico diferencial que possibilitou a exclusão de esclerose múltipla e permitiu o estabelecimento do tratamento oportuno para neuromielite óptica.

Palavras-chave: Lesão cerebral; Sustância branca; Neuromielite óptica; Adolescente.

\section{Resumen}

También conocida como enfermedad de Devic, la neuromielitis óptica (NMO) es una enfermedad inflamatoria autoinmune que afecta al sistema nervioso central, considerablemente similar a la esclerosis múltiple (EM). El objetivo de este trabajo fue comparar las similitudes del cuadro clínico presentado con casos similares encontrados en la literatura médica, abordando los síntomas, diagnóstico y tratamiento. Es un estudio descriptivo, retrospectivo y cualitativo, realizado mediante la técnica de observación directa. Un paciente adolescente varón acudió a nuestro servicio por debilidad en miembros inferiores y retención urinaria y, posteriormente, incontinencia urinaria, durante el ingreso. Tras someterse a una resonancia magnética de cráneo, se evidenció una gran lesión de característica desmielinizante a través de las secuencias T2 y FLAIR, hiperintensa en la sustancia blanca del hemisferio cerebral derecho, con exuberante realce de la imagen contrastada. Posteriormente presentó debilidad en el dimidio izquierdo del cuerpo, con empeoramiento progresivo en algunos días, con imposibilidad de caminar. El tratamiento se inició con pulsos de metilprednisolona e interferón beta, obteniendo un excelente control clínico de la enfermedad. Así, la confirmación diagnóstica solo fue posible gracias a la identificación de una única lesión de la sustancia blanca cerebral mediante imagen y examen serológico, lo que constituyó una herramienta de gran importancia para el diagnóstico diferencial que permitió la exclusión de la esclerosis múltiple y permitió el establecimiento de un tratamiento oportuno para la enfermedad neuromielitis óptica.

Palabras clave: Lesión encefálica; Substancia blanca; Neuromielitis óptica; Adolescente.

\section{Introduction}

Neuromyelitis optica (NMO) is a spectrum of diseases that often affects the central nervous system (CNS), the optic nerves and the spinal cord, and are characterized by inflammation, demyelination, and axonal loss. They are heterogeneous diseases in their clinical, pathological and immunopathogenic course, but they can usually be differentiated based on clinical, imaging, laboratory, and pathological characteristics, although there may be overlap between different diseases due to misdiagnosis (Lassmann, 2007; Wolinsky et al., 2018).

Until recently, any NMO was diagnosed as MS (Wingerchuk et al., 2007; Eshaghi et al., 2021). Therefore, the clarification of these diseases is important to allow them to be distinguished from tumoral or infectious lesions, avoiding unnecessary aggressive diagnostic procedures and treatments, and on the other hand, to allow a more adequate treatment and prognosis for the type of NMO in question (Cañellas et al., 2007; Young et al. 2018; Thompson et al., 2018).

The growth of presumed diagnoses of MS, in turn, increases in cases misdiagnosed, since the clinical diagnosis is based on imaging tests, clinical analyzes, and complementary tests (Fragoso et al., 2012). Since the diagnosis in adolescents is very unusual, studies that characterize the profile of differential diagnosis cases of MS in childhood and adolescence are scarce (Chitnis et al., 2009; Tenembaum et al., 2016; Vigdorovich et al., 2020).

Among the cases seen at the neurology outpatient clinic of São Vicente de Paulo Hospital in Águas Formosas, Minas Gerais State, Brazil, we elected the only case of an adolescent with an inconclusive diagnosis being followed up at our Reference Center located in the Northeast region of Minas Gerais, to observe the similarities of the described case with the consulted literature.

\section{Methodology}

This is a descriptive, retrospective, qualitative study (Fletcher et al., 2003; Yin, 2005; Aragão et al., 2009; Breitkopf et al., 2020), carried out using the technique of direct observation. Patient data were collected through access to medical records and requested tests and were presented in chronological order. Following ethical principles, the patient consented to the disclosure of data and the display of images of his case for academic purposes, by signing the Term of Assent. The patient's data 
were evaluated after the diagnosis and the patient continued to be followed up in a specialized medical service to verify the effectiveness of the proposed treatment.

\section{Case Report}

We present the case of a 16-year-old adolescent who initially manifested a clinical picture of weakness in the lower limbs and urinary retention and, subsequently, urinary incontinence, during hospitalization (Figure 1). Acute flaccid paralysis, medullary schistosomiasis, and Guillain-Barré syndrome were initially suspected.

Figure 1 - Weakness in the lower limbs and urinary retention (A), and urinary incontinence (B).

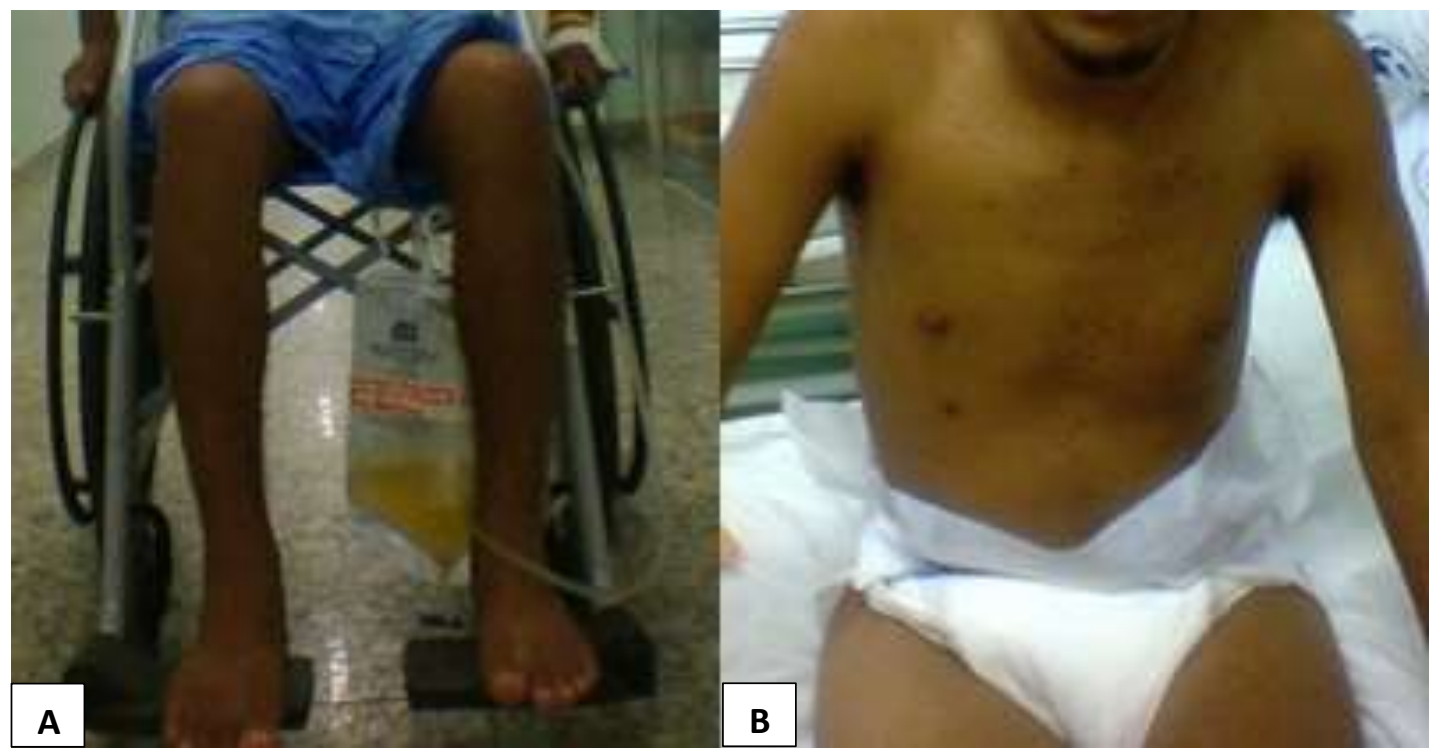

Source: Authors.

The patient underwent magnetic resonance imaging of the thoracic spine, showing inflammatory lesion of the spine between $\mathrm{T} 7$ and $\mathrm{T} 11$, although with progressive improvement in a few weeks, being subsequently submitted to magnetic resonance imaging of the skull, which showed, through the T2 and FLAIR sequences, hyperintense lesion with characteristics demyelinating agents in the left temporal lobe, with no signs of activity. The patient used diapers continuously due to urinary incontinence and was medicated with $10 \mathrm{mg}$ of baclofen every 8 hours, continuously.

When performing a new exam, the patient presented the specific biomarker (antibody against the protein aquaporin 4), considered a strong sign of neuromyelitis optica, despite the absence of ocular complaints. However, the presence of myelitis alone had already caused numbness in one part of the body; weakness of one or more members; imbalance in walking; changes in urine control.

Subsequently, he presented weakness in the left dimidium of the body, with progressive worsening in some days, with the impossibility of walking. Magnetic resonance imaging of the skull showed in the T2 and FLAIR sequences a large lesion with demyelinating characteristics, hyperintense in the white matter of the right cerebral hemisphere, with the exuberant enhancement of the contrasted image (Figure 2). 
Figure 2 - Axial T2-weighted image (A) and Flair (B) showing demyelinating, hyperintense lesion in the white matter of the right cerebral hemisphere.

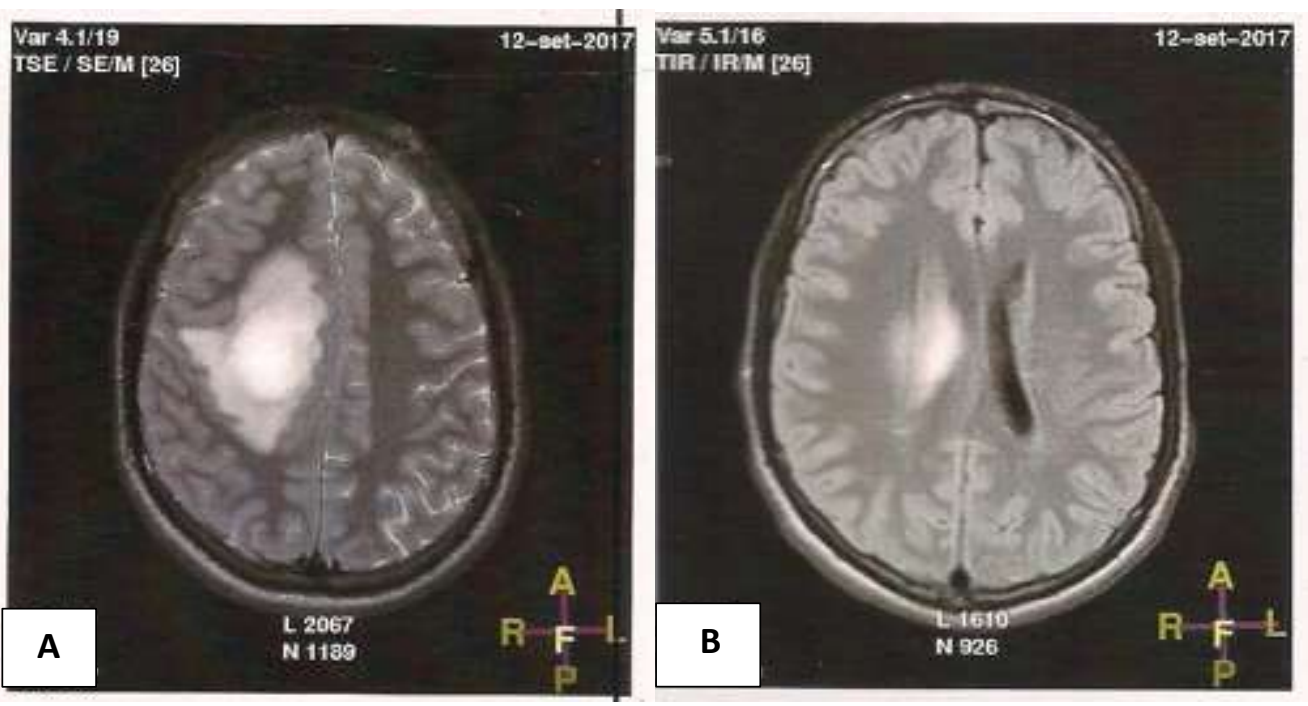

Source: Authors.

Pulse therapy with methylprednisolone was prescribed and administered for 5 days, with a significant improvement in the deficit. Next, a routine CSF exam was performed, which proved to be normal. When using extensive diagnostic tests, no infectious or rheumatological etiology was identified. After the administration of pulse therapy in high doses of corticosteroids, he presented leukocytosis, which did not contraindicate the prescription of immunomodulators. Therefore, as a possible diagnosis for the presented clinical picture was not established, interferon beta $1 \mathrm{a}$ (44 mcg) was tested and prescribed, subcutaneously, three times a week, with good clinical control of the patient.

Interferon monotherapy was maintained, with no adverse effect recorded, allowing the maintenance of satisfactory clinical control despite the diagnostic inconclusion. In contrast-enhanced MRI of the skull performed on 12/12/2018, a diagnostic impression was obtained with the aspect of rotation of the left hippocampus and foci of hyper signal in T2 and FLAIR, located deep white substance, in the upper frontal gyrus to the right, in the temporal gyrus superior to the left and thalamus to the right, without restriction to diffusion or drop in the apparent diffusion coefficient (ADC) map, without evidence of significant enhancement after administration of paramagnetic contrast, which may represent a sequela of a demyelinating lesion, without lesional activity, with permeated gliosis, suggesting the diagnosis of atypical idiopathic demyelinating inflammatory disease, compatible with Neuromyelitis optica (NMO).

\section{Discussion}

Currently, the most common cause of misdiagnosis of MS appears to be non-specific abnormalities of white matter in brain MRI, misinterpretation and misapplication of radiographic diagnostic criteria, as well as the presence of vague or nonspecific neurological symptoms. It has been shown that in up to a third of "normal" people aged 20 to 45 years old, transient neurological symptoms may have no clinical significance. It is also not uncommon to see people with dizziness, numbness, and similar sensory symptoms, without any underlying disease in medical practice (Renard, 2015; Lindemer et al., 2018).

Some considerations must be made when the differential diagnosis between the demyelination plates and other pathologies that resemble them when observed by magnetic resonance imaging (Wingerchuk et al., 2015). Multifocal abnormalities of the periventricular white matter can be seen in normal individuals with no pathological significance. The finding of these areas of anomalous signs increases with age. Over 60 years of age, about $30 \%$ of individuals may have such changes in the periventricular white matter (Minguetti, 2001; Thompson et al., 2018; Filippi et al., 2019). 
To increase the sensitivity of the MRI examination, some diagnostic criteria have been proposed (Verhey et al., 2011). Paty et al., 1988 use the term MRI strongly suggestive of multiple sclerosis for exams that have at least 4 hyperintense lesions or 3 lesions, including at least one periventricular lesion. Fazekas et al., 1988 proposed a different system in which the presence of at least 2 of the following 3 items is necessary for the diagnosis of multiple sclerosis: 1) lesion larger than 6mm, 2) periventricular lesion, 3) fossa lesion later. Both diagnostic criteria have sensitivity and specificity around 90\% 24,26 (Fazekas et al., 1988; Offenbacher et al., 1993; Jeong et al., 2015; Eshaghi et al., 2021).

Brain or spinal demyelination plaques that are enhanced by paramagnetic contrast are acute plaques or are undergoing re-aggravation and in these cases, they can be confused with neoplasms or inflammatory diseases (Guzmán-De-Villoria et al., 2010). The areas of hypointense signals in T1-weighted sequences and hyperintense in T2-weighted sequences in which there is no enhancement after intravenous injection of paramagnetic contrast, correspond to chronic demyelination plaques and are the result of the proliferation of astrocytes and consequent healing (Dos Passos et al., 2018; Datar et al., 2018).

The enhancement of the lesion by the use of contrast shows that there was a breakdown of the blood-brain barrier and can, therefore, measure the activity of the disease. There is clinical and imaging evidence that shows the coincidence of the increase in the size and number of lesions with the clinical outbreaks of the disease. It is also known, on the other hand, that treatment with corticosteroids and interferon causes neutralization of antibodies, decreasing the size and number of lesions, in addition to significant improvement in clinical scores (Minguetti, 2001; Hauser et al., 2017).

The present clinical feature studied was pointed out by a medical team of neurologists as a variant of multiple sclerosis, with striking features of neuromyelitis optica (Jacob et al., 2013; Kansara, 2017; Vigdorovich et al., 2020), capable of causing acute attacks of bilateral or rapidly sequential optic neuritis, leading to severe visual loss, although the patient studied so far has not presented any visual complaint, he may develop this condition in the future if drug treatment is lacking, which may increase the condition of weakness in the limbs, symmetrical paraparesis or quadriparesis, Lhermitte's sign, sensory loss and bladder dysfunction, with a typically recurrent course.

The mechanisms responsible for the white matter injury during neurodegenerative diseases are currently being studied by researchers around the world, mainly at the level of the optic nerve and spinal cord, where the damaging effects on the white matter can be better interpreted (Stys, 2004; Pandit et al., 2015; Mars et al., 2018). An important consequence of this mechanism is that the axons of the white matter, including the passing fibers, can be damaged, generating significant functional deficits that are common in different pathological conditions (Medana, 2003; Schilling et al., 2018).

\section{Final Considerations}

Pathological impairment of white cerebral substance is an important mechanism of the pathophysiology of acute and chronic neurodegenerative diseases, as this group of diseases has similar clinical and radiological characteristics, which makes the differentiation of these specific entities very challenging or even impossible in the first episode of demyelination.

Therefore, this research brings a new perspective to this area of knowledge by encouraging other professionals and researchers to carry out new studies aimed at standardizing and validating diagnostic criteria for definitive NMO.

\section{References}

Aragão, J., Tavares, M. et al. (2009). Como Preparar Um Relato De Caso Clínico. Cadernos UniFOA. Volta Redonda, ano IV, n. 9.

Breitkopf, K., Aytulun, A., Förster, M., et al. (2020). Case Report: A Case of Severe Clinical Deterioration in a Patient With Multiple Sclerosis. Front. Neurol. $11: 782$.

Cañellas, A. R., Gols, A. R., Izquierdo, J. R., et al. (2007). Idiopathic inflammatory-demyelinating diseases of the central nervous system. Neuroradiology; 48:393-409. 
Chitnis, T., Glanz, B., Jaffin, S., \& Healy, B. (2009). Demographics of pediatric-onset multiple sclerosis in an MS center population from the Northeastern United States. Mult Scler. 15:627-31.

Datar, R., Prasad, A. N., Tay, K. Y., Rupar, C. A., Ohorodnyk, P., Miller, M., \& Prasad, C. (2018). Magnetic resonance imaging in the diagnosis of white matter signal abnormalities. Neuroradiol J.31(4):362-371.

Dos Passos, G. R. et al. (2018). MOG-IgG-associated optic neuritis, encephalitis and myelitis: lessons learned from neuromyelitis optica spectrum disorder. Front Neurol. 9: 217.

Eshaghi, A., Young, A. L., Wijeratne, P. A., Prados, F. et al. (2021). Identifying multiple sclerosis subtypes using unsupervised machine learning and MRI data. Nature_Communications. 12(1):2078.

Filippi, M. et al. (2019). Association between pathological and MRI findings in multiple sclerosis. Lancet Neurol. 18, 198-210.

Fletcher, R. H., Fletcher, S. W., \& Wagner, E. H. (2003). Epidemiologia clínica: elementos essenciais. 3rd ed. Porto Alegre: Artmed.

Fragoso, Y. D., Brooks, J. B. B., \& Leal, T. M. S. (2012). Perfil descritivo de esclerose múltipla com início até os 16 anos nos pacientes de um centro de referência do estado de São Paulo. Rev. Paul. Pediatr. 30(4 ):617-20.

Guzmán-De-Villoria, J. A., et al. (2010). Differential diagnosis of T2 hyperintense brainstem lesions: Part 1. Focal lesions. Semin Ultrasound CT MR. 31(3):24659.

Hauser, S. L. et al. (2017). Ocrelizumab versus Interferon Beta-1a in Relapsing Multiple Sclerosis. N. Engl. J. Med. 376, 221-234.

Jacob, A., McKeon, A., Nakashima, I. et al. (2013). Current concept of neuromyelitis optica (NMO) and NMO spectrum disorders. Journal of neurology, neurosurgery, and psychiatry, 84:922-30.

Jeong, I. H., Kim, S. H., Hyun, J. W., Joung, A., Cho, H. J., \& Kim, H. J. (2015). Tumefactive demyelinating lesions as a first clinical event: Clinical, imaging, and follow-up observations. J Neurol Sci. 358: 118-124.

Kansara T. (2017). Neuromyelitis Optica. International Journal of Current Advanced Research, 06(04):3559-3561.

Lassmann, H. (2007). Multiple sclerosis: is there neurodegeneration independent from inflammation? Journal of the Neurological Science. 259:3-6.

Lindemer, E. R., Greve, D. N., Fischl, B., Salat, D. H., \& Gomez-Isla, T. (2018). White matter abnormalities ang cognition in patients with conflicting diagnoses and CSF profiles. Neurology. 24;90(17):e1461-e1469.

Mars, R. B, O’Muircheartaigh, J., Folloni, D., Li, L., Glasser, M. F., Jbabdi, S., et al. (2018). Concurrent analysis of white matter bundles and grey matter networks in the chimpanzee. Brain Struct Funct. 1-13.

Medana, I. M., \& Esiri, M. M. (2003). Axonal damage: a key predictor of outcome in human CNS diseases. Brain. 26:515-530.

Minguetti, G. Ressonância magnética na esclerose múltipla: análise de 270 casos. (2001). Arq. Neuro-Psiquiatr. 59(3A):563-569.

Offenbacher, H., Fazekas, F., Schmidt, R., et al. (1993). Assesment of MRI criteria for diagnosis of MS. Neurology. 43:905-909.

Pandit, L., Asgari, N., Apiwattanakul, M., et al. (2015). Demographic and clinical features of neuromyelitis optica: a review. Mult Scler. 21:845-853.

Paty, D. W., Oger, J. J. F., Kastrukoff, L. F., et al. (1988). MRI in the diagnosis of multiple sclerosis: a prospective study with comparison of clinical evaluation, evoked potentials, oligoclonal banding and CT. Neurology. 38:180-185.

Renard, D., et al. (2015). Cortical abnormalities on MRI: what a neurologist should know. Pract Neurol. 15:257-265.

Schilling, K., Gao, Y., Janve, V., Stepniewska, I., Landman, B. A., \& Anderson, A. W. (2018). Confirmation of a gyral bias in diffusion MRI fiber tractography. Hum Brain Mapp. 39: 1449-1466.

Tenembaum, S., Chitnis, T., Nakashima, I. et al. (2016). Neuromyelitis optica spectrum disorders in children and adolescents. Neurology. 30;87(9 Suppl 2):S5966.

Thompson, A. J., Baranzini, S. E., Geurts, J., Hemmer, B. \& Ciccarelli, O. (2018). Multiple sclerosis. Lancet. 391, 1622-1636.

Verhey, L. H., Branson, H. M., Shroff, M. M., et al. (2011). MRI parameters for prediction of multiple sclerosis diagnosis in children with acute CNS demyelination: A prospective national cohort study. Lancet Neurol. 10(12):1065-1073.

Vigdorovich, N., Ben-Sira, L., Blumkin, L., Precel, R., Nezer, I., Yosovich, K., Cross, Z., Vanderver, A., Lev, D., Lerman-Sagie, T., \& Zerem, A. (2020). Brain White matter abnormalities associated with copy number of variants. Am J Med Genet A. 182(1):93-103.

Wingerchuk, D. M., \& Lucchinetti, C. F. (2007). Comparative immunopathogenesis of acute disseminated encephalomyelitis, neuromyelitis optica, and multiple sclerosis. Current Opinion in Neurology. 20:343-350.

Wingerchuk, D. M., et al (2015). International consensus diagnostic criteria for neuromyelitis optica spectrum disorders. Neurology. 14; 85(2): 177-189.

Wolinsky, J. S. et al. (2018). Evaluation of no evidence of progression or active disease (NEPAD) in patients with primary progressive multiple sclerosis in the ORATORIO trial. Ann. Neurol. 84, 527-536.

Young, A. L. et al. (2018). Uncovering the heterogeneity and temporal complexity of neurodegenerative diseases with Subtype and Stage Inference. Nat. Commun. 9, 4273.

Yin, R. K. (2005). Estudo de caso: planejamento e métodos. 3. ed. Porto Alegre, RS: Bookman, 212p. 